\title{
Meso Abnormal Personality Disorders : Culture Bound Syndrome of Javanese Man in Meranti District Asahan Regency with Psychological Anthropology Analysis
}

\author{
$1^{\text {st }}$ Puspitawati $^{1}, 2^{\text {nd }}$ Dedi Andriansyah ${ }^{2}, 3^{\text {rd }}$ Trisni Andayani ${ }^{3}, 4^{\text {th }}$ Nando Lesmana $^{4}, 5^{\text {th }}$ Nur \\ Alamsyah Putra ${ }^{5}$ \\ \{Puspitawati@unimed.ac.id ${ }^{1}$, dediandriansyah@unimed.ac.id², trisniandayani@unimed.ac.id ${ }^{3}$ \} \\ Department of Anthropological Education, Faculty of Social Science, Universitas Negeri Medan, \\ Indonesia ${ }^{1,2,3,4,5}$
}

\begin{abstract}
This study reveals the Meso/Mesu/Kesu Abnormal Personality Disorder Culture Bound Syndrome in Javanese Men in Meranti Village, Meranti District, Asahan Regency. This study uses an ethnographic method with an Anthropological Psychology approach which is supported by life history interview techniques and observes deeply the cultural activities of the local community to find the factors that cause Meso personality disorder. Meso culture syndrome is a type of personality disorder with bad speech or cursing that occurs repeatedly and is only experienced by Javanese men in this village. The Ethics of Javanese men maintaining family and social harmonization are the one of cause this personality disorder.
\end{abstract}

Keywords: Mesu, Culture Bound Syndrome, Javanese Men.

\section{Introduction}

The problem of personality disorders is a study that consistently gets the spotlight in the discussion of mental health. Personality disorders are a latent problem that continues to grow in the social environment. Data from Riskesdas in 2018, listed on the official website of the Ministry of Health of the Republic of Indonesia on October 15, 2019, explains that 7 out of 1000 households have family members with personality disorders. Then more than 19 million people over the age of 15 years experience mental and emotional disorders. More than 12 million people in Indonesia over the age of 15 are estimated to have experienced depression. The Data shows a very increasing prevalence from the latest data from WHO, which states that in 2010 Indonesian people who experienced personality disorders and ended up in a tragedy of suicide reached 1.6 million to $1.8 \%$ per 100,000 people.

This significant increase then highlights the mental health aspect of oneself, the mental health aspect in the family, and the mental health aspect in the social environment, which are considered some of the factors behind the emergence of personality disorder problems. Ironically, the focus on overcoming issues still seems to focus on curative efforts (healing process). The coping strategy in the form of healing is essential. Still, it is also necessary to understand that it is vital to carry out a preventive problem-solving process so that the characteristics and causes of personality disorders can be recognized and then overcome before the situation worsens. 
What is often overlooked and needs to be understood coherently is that the problem of personality disorders is very closely related to local cultural patterns that are actualized in the interaction process of a community group. Culture plays a role in creating guidelines for ways of life, views, norms, and rules in social relations that are distinctive and local. These guidelines and forms of life then set the pattern of interaction in communal life. However, the reference to action cannot always be internalized in every member of the community, sometimes even putting pressure on the individual psyche, which impacts the emergence of a distinctive and localized personality disorder. This localized personality disorder is known as the cultural syndrome.

Cultural researchers have seen a link between cultural characteristics in local communities and the occurrence of cultural syndromes. Several cases of cultural syndrome were then traced through the focus of Anthropology, Psychology, and Psychiatry. Among them is the Koro culture syndrome in men in China, Amok in the Malay community in Southeast Asia, Senu experienced by the Karo ethnic group in North Sumatra, and Latah, which occurs in Javanese women. Anthropological psychology and psychiatry research on Latah in Javanese women is a study conducted by Hildred Geertz, which has received enough attention from other cultural observers. Hildreed Geertz one of the anthropologists who traced the cultural syndrome of Latah personality disorder in Javanese women in Pare, from the results of his research, describes the relationship between changes in conditions in Javanese society in Pare, the cultural pattern of life causes the problem of maladaptation of Javanese women in social life[1]. This state of maladaptation then gives rise to abnormal behavior of repeating words (Latah) which are accompanied by surprising behavior and sometimes lead to words that mean "dirty"[2].

It is indeed different, but the cultural syndrome is also found to occur in Javanese men in Meranti Village, Meranti District, Asahan Regency. This abnormal behavior is known as Mesu/Meso/Kesuh by the local community. This strange behavior only occurs in Javanese men who live in the villages of the Meranti sub-district, and most cases are in the Meranti village area, the Meranti sub-district. At the same time, the women in the town did not show symptoms of similar behavior. Like other cultural syndromes, perhaps the Meso/Mesu/Kesuh cultural abnormal behavior syndrome is a form of personality disorder that is indicated to be closely related to local cultural patterns (locality). This problem is because this form of abnormal behavior does not occur at all in Javanese men in other areas.

\section{Method}

This type of research is qualitative research with an Anthropological Psychology approach. The Psychological Anthropology approach is always used to reveal the psychological phenomena of society by focusing on the repertoire of local cultural patterns. Because psychological phenomena manifest local cultural patterns that live and are passed down from generation to generation, it would be more appropriate if examined in the realm of thinking, concepts, and concepts. and scientific theory of Anthropology[2].

The method that will be used in this research is the ethnographic method. Researchers use this method to see social phenomena and local culture in detail by being part (life in) of the local community to find a cultural pattern that influences the appearance of abnormal Mesu/Kesu/Meso forms of behavior in Javanese men at the research site. Then in the process of collecting data using direct observation techniques (participatory observation), in-depth 
interviews (deep interviews) in an unstructured manner in the form of living with the community being studied (life in) and tracing information in the life history of the object under study[3].

The data collected was then analyzed following the stages of Spradley's (2017) ethnographic data analysis, namely: (1) Domain analysis was carried out to obtain a general and holistic picture of the cultural patterns of the daily life of Javanese men in Meranti village. Furthermore, (2) taxonomic analysis was carried out after the first step was carried out. This analysis was carried out by collecting the results of observation of participation in activities and unstructured interviews and documentation related to the domains studied. Then (3) the component analysis carried out is to look for differences or contrasts and decide which fields should be studied in-depth related to the research. Then (4), The theme analysis becomes the final part of the relationship between various domains (results of interviews and observations). Theme analysis is a step to holistically understand the "phenomenon" being studied and its interpretation. So that drawing conclusions about Meso personality disorder and the factors that cause it can be described[3].

\section{Results and Discussion}

\subsection{Culture Bound Syndrome and Characteristics of Meso/ Mesu/ Kesuh Javanese Men in Meranti Village}

The term cultural syndrome denotes a behavioral pattern of personality disorder that leads to abnormal behavior. Many of these patterns are considered locally as "disease" or at least suffering, and most of them have local names. Although the presentation of this personality disorder is categorized as a mental disorder that can be found worldwide with symptoms, specific social responses are influenced by local cultural factors. Kiev (2018) explains that the phenomenon of cultural syndrome disorders, most of which are variants of psychosis that are similar to the label of mental disorders in the West, but the location where these psychosis variants are found is connected to the cultural map of the local community[4]. If the cultural map changes, the cultural syndrome will also change. Even the characteristics of personality disorders like this are always associated with local community myths. Attributes like this in mainland Europe are not found at all.

Meanwhile, Dina (Yuniarti., 2020) defines cultural syndrome as a repetitive and localityspecific pattern of abnormal behavior based on problematic experiences that may or may not be related to a particular category of personality disorder diagnosis[5]. The syndrome is usually culture-bound, generally confined to a specific society or region, and localized. The diagnosis frames coherent meanings to string specific repetitive, patterned, and disturbing experiences and cultural observations carried out in real life. There are various forms of cultural syndromes in multiple regions, and each has its characteristics or types depending on the type of local culture. Such as the Piblokto culture syndrome that occurs in the Eskimos, the Windigo culture syndrome that occurs in the Indians, the Amok culture syndrome that occurs in the Malays in Southeast Asian society and the Koro culture syndrome. dominantly occurs in men in China[4].

The study of cultural syndromes is carried out in various regions in Europe and America, and several analyses of cultural syndromes focus on ethnicity in Indonesia. One of the most popular cultural syndrome studies is Hildreed Geertz's (1982) research on Latah in Javanese 
women in Pare, East Java. But apart from that, there are also several other studies, such as Baasir (1974), which describes the results of his research on Koro as a form of syndrome that occurs in Chinese descent in Indonesia. Koro is an anxiety syndrome that suddenly leads to the panic caused by an understanding that his genitals will shrink in and out of his body so that he will die, which generally occurs in men. That person will try to prevent it by holding tightly to his genitals or tying it with a rope, if necessary, asking someone else to keep his genitals constantly. It does not only occur in men of Chinese descent, but Tanumiharja (1984) also traces that Koro also occurs in South Sulawesi. Because Koro in Bugis culture is considered to violate the state of vitality that must be possessed.

Another research related to the cultural syndrome is the research conducted by Aris Fauzan (2017) entitled West Syndrome and Unconscious Rebellion (Critical Analysis of the Shift in Meaning of Amok in Historical Trajectory). The results of this study explain that in its development, amok is used as the language of psychopathology for those who commit brutal acts due to mental health reasons. In addition to the Amuk cultural syndrome, there is also research on the Latah Latah cultural syndrome conducted by Sri Pamungkas (2018) in his writing entitled Interpreting Coprolalia Latah Behavior in Latah Women in the Mataraman Cultural Scope: A Sociopsycholinguistic Study. This study describes the diction expressed between the talkative natives and immigrants who experience slight differences, especially in revealing the male and female genitalia.

Research on the Latah cultural syndrome then received the attention of other researchers, such as that conducted by Andi Saputra Tanjung (2109) entitled A Psycholinguistic Study of the Language Behavior of Latah People: A Case Study of Several Residents of Jalan Garu III Medan Amplas, Medan City. The results of his research revealed that environmental factors and dreams caused some residents of Jalan Garu III Medan Amplas Medan City to behave in conversational language. Furthermore, the study conducted by Habib Rois (2020) regarding the Digitization of Talkative Psychogenic Speech (Acoustic Phonetic Studies). This paper describes that psychological factors are the dominant factors that cause psychogenic talkative disorders; besides, the difference in patterns in other speeches is only related to the number of repeated words.

The community of Meranti Village, Asahan Regency, is a community inhabited by the majority of Javanese ethnicity. Although in this region there are also other ethnic groups, the ratio is very different. Although there is no continuous village census data regarding this matter, from observations while in the village, we can see that the comparison of ethnic composition in this area is almost $80 \%$ filled by Javanese and $20 \%$. They are supplied by other ethnic groups such as Batak Toba, Malay, Minangkabau, Mandailing, and Karo. The state of homogeneity in this village also creates a pattern of living that limits each other between each ethnic group. For example, the Toba Batak ethnic group chooses to live in groups at the front entrance (Gapura) of Meranti Village. In contrast, the Javanese and other ethnic groups prefer to be in areas within the village. According to the local community, this settling-down pattern creates a situation where there is minimal interaction between the ethnic groups living in the village's interior and the Toba Batak people in the front area of Meranti village even though they often pass the road. But on the other hand, social conflicts caused by the dynamics of inter-ethnic interactions are also minimal.

Meranti has broad and fertile land so that many people make a living as rice farmers and gardeners, but many people also choose other jobs such as brick craftsmen, construction workers, and trading at home. The condition of the place of work that is so close to home creates a pattern of family maintenance and division of domestic roles that women carry out. Still, men are also involved in it, without reducing the part of men in public activities such as 
full involvement in the deliberation process, cooperation, and other social activities. The participation of men's dual roles in public and domestic affairs has also been conveyed by Geertz from the results of his research described in his phenomenal book about Javanese society in Modjokuto, that the Javanese kinship system, especially in Modjokuto, is indeed accurate. Adopts a bilateral/parental approach where both parties (wife and husband) both contribute to the pattern of parenting and division of labor, it's just that it's still visible where the role of men is so dominant over women for some things, especially in the space of implementing traditions, cooperation and also decision-making. According to Geertz, this cannot be separated from the influence of Islamic religious doctrine wherein the public sphere is still given more role flexibility for men than for women[6]. The same thing is also actualized in Meranti village. Still, without realizing it, this situation of division of roles which is cultured from generation to generation in the family system, is one of the triggers for the Meso/Mesu/Kesuh personality disorder, especially for Javanese men in Meranti Village.

Meso/Mesu/Kesuh is a word meaning that has so many words but has the same meaning. Meso/ Mesu/ Kesuh is a word that comes from the local Javanese language, which is understood as a state of upset. The elaboration of the meaning of Meso/ Mesu/ Kesuh is a condition in which a person experiences discomfort (annoyance) due to various reasons that are buried within themselves. Meso/ Mesu/ Kesuh becomes a form of behavior. An individual (Javanese man) feels annoyed and expresses his annoyance with harsh words or swearing but is not poured out on the person concerned. So that resentment also brings a form of behavior, regretting the life passed by oneself and sometimes cursing oneself.

Meso / Mesu / Kesuh is not a behavior of outburst of anger that is blind or in the form of physical violence that is done either to oneself or to others, but only in verbal form (grunting) and tends to be done alone. Even though it is a form of personality disorder, this behavior itself does not necessarily have a negative meaning for the local community. This is considered standard among Javanese men in this village, especially men who are married. Meso / Mesu / Kesuh, some even call it grundil, or grandil is also understood by the community as a word that describes feelings of anger, disappointment, dissatisfaction, and everything that does not wear the heart so that it causes verbal pronunciation of it. From the results of observations and interviews that have been carried out, the author then divides the state of Meso / Mesu / Kesuh into three levels, namely:

Low-level Meso/Mesu/Kesuh. Low anxiety is a verbal and open expression in the form of an outburst of anger that is only directed at oneself or others in a rare intensity. This means that the trouble at this level is only an individual scolding other individuals without any dirty words in the pronunciation.

Medium level Meso/Mesu/Kesuh. Moderate distress is verbal and open pronunciation in a high tone and using harsh words in the process of exposing one's emotions and anger to someone. However, in this moderate situation, the individual is only talking rudely without any physical actions that try to harm others.

High level Meso/Mesu/Kesuh. High anger is throwing words that are the fruit of anger due to a situation or someone's actions that irritate an individual on a large scale. This means that harassment at this level is not only in the form of verbal abuse but also uses physical actions, such as throwing the individual's belongings in question. 
According to the community, Meso/Mesu/Kesuh itself also occurs in men and women, and it's just that there is a difference between male and female problems. Women are considered more expressive in venting their frustrations than men so that it is not buried and does not become a personality disorder. Meanwhile, men tend to hold back, sometimes silent or express it, but not to the person concerned. Data from interviews with informants show that there is a confession that Meso/Mesu/Kesuh only occurs in married men or married couples. According to the community, problems in the household are considered to be the most significant factor causing this personality disorder as a result of not building communication in resolving household dynamics. The public's view of this is supported by the authors' findings where Meso/Mesu/Kesuh is only experienced by men who are "aged" and have been married for quite a long time.

There are no cases of this personality disorder experienced by young and unmarried men and those already married. Of course, this situation implies that this personality disorder does not appear suddenly, but because a condition that has lasted for a long time in married life and is not resolved then disrupts the personality structure of men. It not only becomes a problem due to natural things that arise from within but is also influenced by cultural pressures.

Freud (2018) explained that the structure of the human personality of women and men both consist of the Id as an internal structure that is in contact with biology, then the Ego, which is in touch with reality, and the Superego as a personality structure (inner part) that represents the values of external reality, so that the superego functions to carry out the impulse to comply with the values that apply in the outer. The development of this personality structure differs depending on the cultural construction of women and men from the values and norms that exist in a communal's artistic elements. So that the values built and instilled by the collective then create a response guide to the personality structure between men and women[7].

What was conveyed by Freud became the basis for thinking that the response to anger and resentment that manifested gave rise to two personality states that provide expressive or permissive encouragement? The explicit nature so shows the embodiment of the emotional state in oneself, while the permissive nature prefers to be calm or keep the emotional state inside. An author [8] from his book for a result of a long experience of living with the Javanese, describes that the life frame of the Javanese people in the Javanese Thinking Sketch teaches them to take better care of social cosmology. It is an order that creates harmonization of family and community life even though it has to be at the expense of all feelings. Javanese people prefer to subdue their emotional responses to choose the order that must be maintained[8].

This personality structure cannot be separated from the influences of local cultural values and norms. The importance and norms that are learned and inherited are then internalized through the parenting system in the family (behavior pattern) so that they become a differentiator for Javanese women in Meranti village who can vent their frustration and anger on the individual concerned, but this cannot happen to the man. Feelings of rage and anger are preferred to be buried so deeply that no conflict will create disharmony in the family and social environment. It's just that, according to the community, the pent-up annoyance will not be buried forever. Now and then, he will be expelled, but to maintain the harmony, the men seem to prefer to express their annoyance, not to the person in question. Choose to speak for yourself, curse yourself and sometimes lead to a state of mourning for life.

The outburst of emotion and resentment is natural from the reality of life (das Sein) that is not by expectations (das solen). The local ethnic culture strongly influences this raw feeling in its discharge. We can see there are types such as in Javanese men who are different from other 
ethnic personalities, who are more expressive, as in the Batak ethnic man who, according to the author, is very famous with a very expressive personality in forgetting his emotional state. The author has asked this to acquaintances who are ethnic Batak, and according to them, it is a very relief rather than suppressing it, and the person concerned who we don't like can know where the fault lies when expressed directly.

\subsection{Javanese living ethics and the causes of Meso/Mesu/Kesuh}

Javanese ethnics are known to uphold the values of etiquette, ethics of politeness, and harmonization in their family and social life. The concept of ethics it can be understood as a complex of norms and judgments used by the community concerned to determine how the members of that community should live their lives[9]. In terms of the complexity of norms and ethics, Javanese society regulates their interactions through two principles: the principle of harmony and respect. These two principles then hold, demand, and guide all forms of exchange that lead to open conflicts that must be prevented to maintain harmony. Endraswara (2010) explains that harmony is a social regulatory law, where harmony must be prioritized in Javanese life ethics. Harmony demands something from individuals and becomes an inherent personality to understand their obligations while maintaining their efforts to guarantee their rights but not to disturb social harmony[10].

The principle that essentially wants to lead to this harmony turns out to be, in some cases, also showing the existence of problems in it. Poerwanto (2020), in his book entitled Culture and the Environment, describes that the shy personality of the Javanese as a form of maintaining social harmony has turned out to be the main factor in environmental problems in the village[11]. Environmental pollution in the form of waste disposal, which business owners often carry out into sewers or rivers in villages, has never received a response from neighbors who live close to the factory or production location of the business. The neighbors are very aware of this situation. Still, they do not want to interfere because they feel reluctant to the business owner, known to be very generous and kind to the residents. This feeling of reluctance and discomfort in maintaining the principle of social harmony causes environmental pollution problems in the village to continue to occur without any warning or attention shown by residents. The role of the community as one of the tools of social control, including environmental management, is no longer working correctly due to this unethical attitude.

Returning to the discussion of Meso/Mesu/Kesuh personality disorder in Javanese men in Meranti Village, from the observations during life in Meranti Village, the author then finds various factors that cause Meso/Mesu/Kesuh personality disorders in Javanese men in the village. Meranti. This is indeed caused by household problems but can be detailed as follows:

Division of domestic roles involving men. The involvement of men in helping with domestic work while also carrying out public roles makes men (husbands) have views and concepts of assessment about the implementation of domestic functions that are right or wrong, optimal or less than optimal. So that sometimes what women (wives) do at home, often get a unilateral assessment from men (husbands). Incompetence in doing homework, incompetence in parenting is usually an embedded judgment. This creates resentment in men, but it cannot always be conveyed to the wife. If this they said, there will be disharmony in the family and domestic conflict. Men choose to keep this situation under wraps, leading to the Meso/Mesu/Kesuh personality disorder. 
The role of women is not optimal, as experienced by the informant known as Wak Rebo, who confirmed that married people tend to have the potential to have a higher level of anxiety than those who are single. Distress mainly occurs in married people and can be caused by many things, such as unfinished homework problems, caring for children who are considered incompetent, and services to husbands who are considered less than optimal. However, this is not communicated to the wife because usually, the wife will defend herself, and conflicts occur in the household.

Sedentary pattern that is Virilocal. Many couples, after marriage, prefer to live in their own homes but are still in the male family environment (virilocal). This sedentary pattern makes the situation in the family not always accessible, especially in emotional outbursts. The presence of relatives around the home makes men try to maintain the dignity/good name of harmony in the family by not expressing their emotions openly either to their wives or children. However, most cases of Meso/Mesu/Kesuh occur because of problems between husband and wife. The men (husbands) feel reluctant and do not want the issues in their household to be known by their relatives, which will be able to open up opportunities for the relatives to interfere in the problem. So that the emotional outbursts that are being held back give rise to inner pressure, annoyance, or emotional feelings that you want to express but are still held and buried in such a way that these men curse or scold themselves.

The problematic pressure of domestic needs and child care. Economic problems in this context are related to work and meeting the needs of essential goods and materials for the family. Financial issues have become one of the foundations in many things that happen both in society and the family. The economic problems in this paper are related to the people's work who is mostly farming and trading. The issues faced tend to be the same, namely regarding the price of agricultural products, which are lower than the price of feed or seeds, the stalls are empty of customers, and the situation is getting more and more difficult as time goes by. These economic problems can impact interactions with those closest to them, such as being annoyed that the price of an item or staple/farm product is low, so someone will be lazy to work on it or sell it and blame the situation the people around them.

Work environment adjacent to the place of residence. It should be noted that the work done mainly by the men in this village is farming, which is located not too far from home. In addition, there are also forms of entrepreneurship in brick making, workshops, shops, and other entrepreneurs who are also located close to where they live. On the one hand, this situation has a positive impact where costs are minimized because they do not require transportation costs to get to work and food costs. Their wives always bring the men at work breaks lunch, or the men take it themselves to the house close to their workplace. But on the other hand, this adds to the psychological pressure on men where they can directly observe the actualization of domestic roles carried out by their wives and minor problems in child-rearing.

Children often complain to their father about the things that he experienced in their friendship or at home. In addition, minor misbehavior committed by children around the father's workplace can trigger emotional feelings. This feeling cannot be expressed because so many colleagues and other people around will witness the conflict in the family. From the results of interviews conducted by the author, most men prefer to hold back those emotions, but they will still be stored in their hearts. Moreover, this is often complicated by work problems experienced such as targets not being achieved, profits not being obtained, fields experiencing pest problems, and so on. 
Personality with the permissive characteristic of emotional self-expression from a married life is not a character that suddenly appears in Javanese men. Socio-cultural construction and detribalization so influence decision-making to suppress their emotional feelings. This is also very closely related to many internalized cultural values related to addressing problems. Moreover, the Javanese society is a society that highly values order, balance, and harmony in life[12]. Values and teachings that prioritize maintaining peace and not disintegrating in the family or the social environment are also embedded in many Javanese philosophies of life. One of the philosophies of life that are always taught is " Trima yen ketaman, Sakserik sameng dumadi, Tri legawa nalangsa srah ing Barthara (sincere to lose without regret, patient if others hurt the heart, the third is to be open-minded while surrendering to God), where there is an emphasis on prioritizing patience when hurt by others and submitting vengeance to God Almighty. An attitude that is taught to uphold the value of spirituality in every problem of life.

The values in this philosophy of life strengthen the personality characteristics of the Javanese, which emphasize more on maintaining inner peace, harmony, and balance of life with an accepting attitude towards all events that occur while placing the individual under society and society under the universe[13]. Although we cannot close our eyes that the current situation of maintaining this harmony has begun to experience a shift, where so many phenomena are seen in the social life of the Javanese people in other areas where conflicts are open and put the principle of harmony and harmony aside.

Although we cannot close our eyes that the current situation of maintaining this harmony has begun to experience a shift, where so many phenomena are seen in the social life of the Javanese people in other areas where conflicts have been open and put the principle of harmony and harmony aside, Javanese ethnicity is also inseparable from negative personality traits and can destroy the principle of balance. Supeno (2019), in his work entitled Modern Javanese Man, provides a description of some negative characters of Javanese society amid modern life that he observes today. Among them are (1) syncretic god, (2) feudal and authoritarian, (3) vengeful and cruel, (4) hypocrite, (5) lack of respect for own nation's work, (6) lack of discipline, (7) likes to party and Mo Limo (The habit of carrying out the five taboos in Java, namely main is gambling, madat is drunk on drugs, minum is drunken liquor, maling is the thief stealing and madon which means playing with women. So if this continues without any deconstruction process in embedding Javanese culture that is full of noble values, there will be many young Javanese who experience a shift in living social life without a cosmology that must be kept in order[14].

\section{Conclusion}

The results of the study on the Cultural Syndrome of Meso Abnormal Personality Disorder in Javanese Ethnic Men in Anthropological Psychological Analysis in Meranti Village, Meranti District, Asahan Regency, gave several conclusions, that is Mesu/Mesu/Kesuh, which means annoyed, is a personality disorder in Javanese men in Meranti Village manifested in anger, cursing, and swearing suddenly but when he is alone. The factor that causes some Javanese men in Meranti Village to experience Mesu/Mesu/Kesuh personality disorder is not genetic factors or personality problems but household socio-cultural problems. Among them is the division of domestic roles involving men, a virilocal pattern of settling after marriage, the problematic pressure of domestic needs and child care, and a work 
environment close to the place of residence. Mesu/Mesu/Kesuh personality disorder is a form of the inner conflict of Javanese men in Meranti Village. They are enculturated by Javanese ethnic living ethical values that teach the obligation to maintain social harmony and harmony, with resentment poured out on the individual concerned. Cultural syndrome is a personality disorder that needs to be understood by Javanese men in Meranti Village. So this can anticipate that this personality disorder does not happen to many other Javanese men in this village.

Acknowledgments. The authors would like to thank the Institute for Research and Community Service (LPPM) the State University of Medan for funding assistance in this research. So that this research about Meso Abnormal Personality Disorder : Culture Bound Syndrome of Javanese Men in Meranti Village District Asahan Regency With Psychological Anthropology Analysis can be completed.

\section{References}

[1] Hildreed G. Keluarga Jawa. Jakarta: Pustaka Grafiti Pers; 1982.

[2] James D. Antropologi Psikologi. Jakarta: Grafiti Pers; 2017.

[3] Spradley J. Metode Etnografi. Yogyakarta: TWY; 2017.

[4] Dyson L. Antropologi Psikologi dan Psikiatri. Surabaya: CV Putra Media Nusantara; 2018.

[5] Yuniarti KW, et al. Psikopatologi Lintas Budaya. Yogyakarta: Gajah Mada University Press; 2020.

[6] Geertz C. Mojokuto Dinamika Sosial Sebuah Kota di Jawa. Jakarta: Pustaka Grafitipers; 2000.

[7] Freud S. Ego dan ID. Yogyakarta: Tanda Baca; 2018.

[8] D’Almeida WB. Kehidupan Jawa dalam Sketsa Orang Jawa. Yogyakarta: Indoliterasi; 2020.

[9] Astiyana H. Filsafat Jawa. Yogyakarta: Warta Pustaka; 2006.

[10] Endraswara S. Etika Hidup Orang Jawa. Jakarta Selatan: NARASI; 2010.

[11] Poerwanto H. Kebudayaan dan Lingkungan dalam Perspektif Antropologi. Yogyakarta: Pustaka Pelajar; 2010.

[12] Endraswara S. Falsafah Hidup Jawa. Yogyakarta: Cakrawala; 2016.

[13] MH Y. Falsafah dan Pandangan Hidup Orang Jawa. Yogyakarta: Absolut; 2010.

[14] Supeno H. Manusia Jawa Modern. Banjarnegara: @ktorPublishing; 2019. 